$\begin{array}{lllllllllllllll}\text { A } & \text { R } & \text { T } & \text { I } & \text { C } & \text { L } & \text { E } & \text { S }\end{array}$

Bartłomiej Rusin

Jagiellonian University, Kraków, Poland

\title{
Anti-Jewish excesses on Bulgarian territories of Ottoman Empire during the Russo-Turkish War of 1877-1878
}

Outline of content: The article discusses the subject of anti-Jewish excesses in the territories south of the Danube during the Russo-Turkish War of 1877-1878. Acts of violence against Jews occurred mainly in the first phase of the war, in smaller locations seized by Cossack and Russian troops. The main motivation behind those incidents was a desire for personal profit, but a certain role was also played by traditional stereotypes and general mistrust towards this minority. The Jews, as a small and weak group, had no possibility to protect themselves from the aggression of others, and their only means of defence was escape. The anti-Jewish incidents, which occurred during the war, represented a turning point in the attitude of the local Slavic population towards this minority, marking the birth of modern anti-Semitism in Bulgarian lands.

Keywords: Russo-Turkish War, anti-Jewish incidents, history of Bulgaria, anti-Semitism

The Bulgarian historiography devoted to the Russo-Turkish war of 1877-1878 may already be vast, but it remains nonetheless a subject of inexhaustible interest for native researchers. This is because, among other reasons, this conflict is perceived by the majority of Bulgarians as a war of national liberation, which led to the restoration of their statehood - at first in the form of the autonomous Principality of Bulgaria, remaining under the suzerainty of the Ottoman Empire. ${ }^{1}$ Recognising the Russian Empire as their protector, the Bulgarian population greeted the decision of their country joining the war against Turkey with enthusiasm, and partook actively both in battles and in the operations behind the front lines. ${ }^{2}$

1 Ultimately, the autonomous Principality of Bulgaria gained its independence in 1908; see Z. Klejn, "Okoliczności towarzyszące ogłoszeniu niepodległości Bułgarii w 1908 roku”, in: Państwa europejskie na drodze do niepodległości ( $w$ drugiej połowie XIX i XX wieku). Studia ofiarowane Profesorowi Marianowi Zgórniakowi, eds. I. Stawowy-Kawka, W. Rojek, Kraków, 2003, pp. 73-77.

2 Seе: К. Калчев, Бесарабски българи опълченци в руско-турската война 1877-1878, Veliko Tarnovo, 1995; С. Дойнов, Българската общественост и руско-турската освободителна 
In contrast, the fate of the Jewish population in the war-stricken Turkish territories south of the Danube, inhabited mostly by Orthodox Bulgarian population, remains a lesser known aspect of this conflict. The reason is at least twofold. First of all, Russia's fundamental role in the reinstatement of the Bulgarian statehood has inspired the concept of Russia acting as defender of the Orthodox Slavic population in the Balkans (further strengthened in the years 1944-1989), which compelled to perceive this country solely in a positive context. ${ }^{3}$ The myth of "Russia the saviour" caused the Bulgarian people to repress all ideas that would belie the adopted interpretation, including the excesses against the Jewish population perpetrated mainly by Cossacks serving in the Russian army, but often by the local Slavic population as well. ${ }^{4}$ In turn, the actual participation of the Bulgarians in anti-Jewish incidents would not fit another generalisation, which persists in the national consciousness and historiography, namely the idea of Bulgaria as a traditionally tolerant country, free from any manifestations of anti-Semitism. This second myth was decisively influenced by the events of World War II, when Bulgaria refused Germany's request to deport their local Jewish diaspora, thus saving more than 48 thousand Jews from death in extermination camps. ${ }^{5}$

Undoubtedly, the resentment of the Bulgarians was directed chiefly against the Muslims, as representatives of the state that had been exploiting Orthodox Slavs in the region for several centuries. ${ }^{6}$ In comparison, the occurrences of violence

война 1877-1878, Sofia, 1978; B. Rusin, "Polityka Rosji na Bałkanach a udział Bułgarów w wojnach rosyjsko-tureckich w XIX wieku”, in: Ślady obcego panowania w języku, kulturze i świadomości narodów południowosłowiańskich, ed. R. Sendek, Kraków, 2011, pp. 103-115.

${ }^{3}$ Russia's merits with respect to the freedom of Bulgaria would constitute the historical background for the Bulgarian-Soviet alliance; see: R. Daskalov, Debating the Past. Modern Bulgarian Historiography - From Stambolov to Zhivkov, Budapest \& New York, 2011, pp. 26-42.

${ }^{4}$ P. Stefanov, "Bulgarians and Jews throughout history", Religion in Eastern Europe, 22 (2002), no. 6, p. 6 .

5 At the same time, Bulgaria is responsible for the deportation of Jews from the territories it has annexed in 1941. In March 1943, the Jews from Western Thrace and part of Aegean Macedonia (then called Belomorie), as well as from eastern Vardar Macedonia and Pirot, were deported and murdered at the Treblinka extermination camp; see F. Chary, Bulgarian Jews and the Final Solution, 1940-1944, Pittsburgh, 1972; M. Bar-Zohar, Beyond Hitler's Grasp. The Heroic Rescue of Bulgaria's Jews, Massachusetts, 1998; T. Todorov, The Fragility of Goodness. Why Bulgaria's Jews Survived the Holocaust, London, 2001. A number of important findings on the fiscal exploitation of the Jews in Bulgaria and annexed territories can be found in Rumen Avramov's monograph: "Спасение" и падение. Микроикономика на държавния антисемитизъм в България 19401944 2., Sofia, 2012. An extensive two-volume collection of documents was prepared to facilitate the re-evaluation of Bulgaria's responsibility for the deportations from Macedonia, Pirot and Belomorie: Депортирането на евреите от вардарска Македония, беломорска Тракия и Пирот. Март 1943 г. Документи от българските архиви, vols. 1-2, eds. Р. Аврамов, Н. Данова, Sofia, 2013.

6 The Russo-Turkish war of 1877-1878 not only resulted in a large-scale migration of the Turkish population during the conflict, but also constituted another step in the demographic restructuring 
against Jews and looting of their property were incidental, their main cause being the anti-Semitism and greed of Russian soldiers who fought in this part of the Ottoman Empire, but also the ambiguous stance of the Jews themselves on the Bulgarian struggle for national liberation, which had entered its decisive phase during the war of 1877-1878. ${ }^{7}$ Arguably, some Bulgarians were also associating the local Jewish community with the person of British Prime Minister Benjamin Disraeli (also of Jewish origin), who was opposed to the restitution of the Bulgarian state during the crisis of 1875-1878, and was commonly believed to be the main responsible for the division of Bulgarian lands into several parts following the Congress of Berlin. ${ }^{8}$ However, Judeophobia was everything but new this region, as it could be traced even back to the $9^{\text {th }}$ century. Certain stereotypes about Jews had been evolving here for several centuries, and the war events of 1877-1878 have had a key influence on their manifestation. ${ }^{9}$ It should be noted nonetheless that the degree of antipathy towards this minority was much lower in ethnically Bulgarian lands than in other parts of Europe.

At the outbreak of war, the European part of the Ottoman Empire was most probably inhabited by approximately $70-100$ thousand Jews. This number also included Bulgarian Jews; however, an exact count might be impossible, as statistical data from that period often appears incomplete or contradictory. Bulgarian historian David Koen quotes a variety of sources on this subject, indicating that

of the Balkans. The multi-cultural and multi-religious community of the Ottoman Empire was being suppressed by the newly created countries, the policies of which were aimed at creating ethnically homogeneous societies through the elimination of foreign groups, mainly by means of massacres, displacement and other discriminatory activities; see: P. Üre, "Immediate effects of the 1877-1878 Russo-Ottoman War on the Muslims of Bulgaria", History Studies, 13 (2013), pp. $153-154$.

7 M. Neuburger, “The Russo-Turkish War and the 'Eastern Jewish Question': Encounters Between Victims and Victors in Ottoman Bulgaria, 1877-8, East European Jewish Affairs, 26 (1996), no. 2, p. 57.

${ }^{8}$ Disraeli's name has later become a synonym of hatred towards Bulgarians; the British politician was often compared to the medieval Byzantine emperor Basil II (dubbed the Bulgar Slayer), who waged a long-term war against the Bulgarian state. Basil owed this nickname to his decision of blinding thousands of Bulgarian prisoners after the Battle of Kleidion, leaving one eye to every hundredth soldier who would then lead his unit back to their country; see: Р. Генов, Дизраели, еврейството и антисемитизъм в България, http:// dialogueeurope.org/uploads/JewsCol/ Panel101.pdf, p. 25 (access: 3 January 2015).

9 Stefanov, Bulgarians and Jews, p. 2. For more on Bulgarian stereotypes about Jews, see: О. Тодорова, “Образът на 'нечистия евреин' в българската книжнина от XVIII - началото на ХІХ век и във фолклора”, Български фолклор 1993, nо. 3, pp. 10-21; Д. Ангелов, “Представа за 'другия' в българския песенен фолклор”, Българска етнология 1997, nos. 1-2, pp. 109-121; О. Тодорова, Евреите в българската словесност от началото на ХІХ век до Освобождението, Либерален преглед 2012, по. 3, pp. 256-276. According to a legend written down by nineteenthcentury writer Ivan Vazov, the medieval Bulgarian capital Tarnovo (now Veliko Tarnovo) fell due to the treason of Jewish resident, who opened the gates of the fortress for the Turks; see: Генов, Дизраели, р. 25. 
the number of Jews in Bulgaria ranged between 10 and 20 thousand. ${ }^{10}$ In contrast, data from a census carried out by the post-war interim Russian administration claims that the Bulgarian lands were inhabited by 14,263 Jews. The 1880 censuses conducted separately in the Principality of Bulgaria and Eastern Rumelia (autonomous province within the Ottoman Empire) showed slightly larger numbers. The Principality had a population of 14,342 Jews; in Eastern Rumelia, the Jewish minority consisted of 4,177 people. ${ }^{11}$ The first census in a united Bulgaria was carried out in 1887 . According to its results, the country was already inhabited by 24,352 people of Jewish nationality. ${ }^{12}$

In the European part of the Ottoman Empire, the Jews (mostly Sephardim) lived in unrelated communities, governed by rabbis empowered with considerable autonomy. Unlike the Orthodox population, during the first decades of Turkish dominance over the Balkan Peninsula, they enjoyed many privileges, mainly due to their experience and knowledge in many fields, particularly in trade. At one point, their contribution to the Ottoman economy even was even considered "invaluable", which earned them accusations of being Turkish spies from some of the more suspicious Bulgarians. ${ }^{13}$

The situation, however, began to change with the gradual decomposition of the state and an increase in the fiscal burden imposed on the non-Muslim population, which also affected the Jews. ${ }^{14}$ Recurring anti-Semitic incidents raised strong concern, the Jewish minority being persecuted by both Orthodox Christians and Turks (since the sixteenth century). ${ }^{15}$ In 1864, three Jews from Sofia were forcibly baptised by a Greek priest, then imprisoned in a monastery. In 1867, the local authorities of Eski-Zaara (now Stara Zagora) carried out unlawful searches in the Jewish quarter; two years later, the local authorities in Rusçuk (now Ruse) reacted negatively to the warm welcome offered by the local Jews to

10 Д. Коен, Българските евреи по време на Освобождението от турско владичество, in: id., Евреите в България (1878-1949). Студии, Sofia, 2008, p. 14. Originally published in: Годишник на Обществено-културно-просветна организация на евреите в България (hereinafter: Годишник ОКПОЕ) 1969, vol. 4, pp. 169-183. The quotes in the present article were taken from a newer edition of Koen's text.

11 The census in the Principality of Bulgaria was based on the criteria of religion, gender and spoken language. In Eastern Rumelia, the criteria were nationality and gender; see: Коен, Българските евреи, рр. 19-21.

12 А. Калев, “Данни относно демографското положение на българските евреи (1887-1940)”, Годишник ОКПОЕ 1981, vol. 16, p. 100.

13 П. Неделева, “Място и роля на еврейската общност в българските земи (от османско владичество до 30-те години на ХХ в.)”, Юридическо списание на НБУ 2013, по. 2, p. 38.

14 The slow decline of the Ottoman Empire led to the dissolution of the Jewish community living within its borders. The financial situation of this minority began to deteriorate in the seventeenth century, thus hampering significantly the level of cultural development and education among Bulgarian Jews; see: ibid., p. 41.

15 Й. Мордехай, “Освобождението на България от османско владичество и българските евреи”, Годишник ОКПОЕ 1968, vol. 3, p. 11. 
the Austro-Hungarian Emperor Franz Joseph I while he was travelling through this town. ${ }^{16}$ The deteriorating situation of the Jewish population in the area prompted some to choose emigration; ${ }^{17}$ the vast majority, however, began to perceive the Bulgarian pro-liberation movement more favourably, as their only hope for the improvement of their complex living conditions in the declining empire. The revolutionaries were supported especially by the wealthier and better-educated members of this minority, who constituted the nucleus of the emerging Bulgarian bourgeoisie, and wished for the abolition of the feudal relations prevailing in the country and a rapprochement with the Western powers. It should be noted as well that some influential pro-liberation activists also displayed a friendly attitude towards ethnically foreign residents - especially Vasil Levski, who was an avid supporter of equal rights for Bulgarians, Turks, Jews and all others ethnic groups. ${ }^{18}$

However, other milieus within the Jewish community feared the effects of national liberation, alarmed by Russia's status as protector of the Bulgarians and by the accounts of persecution of their minority occurring in that country. ${ }^{19}$ Bulgarian Jews also felt threatened by the participation of neighbouring Romania in military operations on the Russian side (since August 1877). This country had been displaying strong nationalist and discriminatory tendencies in the past, with their 1866 Constitution stripping non-Christians of political rights (art. 7). ${ }^{20}$ The acts of violence against the Jewish minority in Galați (1859 and 1867), Bucharest (1867 and 1868), Tulcea (in 1872), and in Russian cities such as Odessa (1871), were also reported in the Bulgarian press. ${ }^{21}$

16 M. Franco, Essai sur l'histoire des Israélites de l'Empire Ottoman depuis les origines jusqu'à nos jours, Paris, 1897, pp. 212-214.

17 The Sephardic Jews fleeing the Ottoman Empire headed primarily to Vienna. Among these were also Jews originating from Bulgarian territories; see: E. Weinzierl, The Jewish Middle Class in Vienna in the Late Nineteenth and Early Twentieth Centuries, Working Paper, Centre for Austrian Studies, October 2003, http://www.cas.umn.edu/assets/pdf/WP011. PDF, p. 4 (access: 5 January 2015).

18 A. Vezenkov, "Reconciliation of the spirits and fusion of the interests. 'Ottomanism' as an identity politics", in: We, the People. Politics of National Peculiarity in Southeastern Europe, ed. D. Miskhova, Sofia, 2011, pp. 24-25. Some academics also mention Sophronius of Vratsa (1739 - ca 1813), who was rescued by a Jew, and writer and political activist Luben Karavelov (18341879); see: Мордехай, Освобождението, p. 13. P. Stefanov disagrees with this point of view, claiming that Karavelov and fellow revolutionary and writer Hristo Botev (1848-1876) both have made remarks about Jews purely based on stereotypes; see: Stefanov, Bulgarians and Jews, p. 6.

19 Above all else: the anti-Jewish excesses in Odessa in 1821, 1859 and 1871; see: I.M. Aronson, Troubled Waters. The Origins of the 1881 Anti-Jewish Pogroms in Russia, Pittsburgh, 1990, p. 245; Ш. Шеалтиел, Ционизмът в България. Особености на едно лидерско движение, Sofia, 2012, pp. $14-15$.

20 S. Marton, 'Designing citizenship. The 'Jewish question' in the debates of the Romanian parliament (1866-1869)", Quest. Issues in Contemporary Jewish History. Journal of Fondazione CDEC 3 (July 2012), pp. 35-55.

${ }_{21}$ Коен, Българските евреи, р. 15. 
The situation of the Jewish community in Bulgaria at the outbreak of the Russo-Turkish war was therefore highly complicated. As a small group, they were not in a position to take care of their own safety, which forced them to turn to one or another of the warring parties for protection. Their inability to settle for one unambiguous stance, intensified by a concurrent lack of declaration of neutrality towards the ongoing conflict, aroused mistrust among Bulgarians and angered the Russian troops, thus also leading to an even higher number of anti-Jewish incidents during the war.

These acts of violence occurred since the very beginning of the war; after the Imperial Army crossed the Danube west of the city of Ruse, the Jewry of Svishtov suffered humiliation at the hands of the Christian population, only to then be robbed of all of their belongings. ${ }^{22}$ Several Jews also died on the scene. ${ }^{23}$ According to some accounts, the Bulgarians began lynching and attacking Turkish and Jewish residents unprovoked, resorting even to killing women and children without mercy. Their actions were facilitated by Russian General Iosif Gurko who, after disarming the Turkish units, decided to transfer the acquired weapons to Bulgarian civilians. ${ }^{24}$ Other academics suggest, however, that the persecution of ethnically foreign groups began with the arrival of Cossack units to the city. The Bulgarians, accompanied by small groups of Vlachs and Romani, were supposed to enter the abandoned Turkish neighbourhood and loot the houses. It was probably then that the houses of local Jews, having not been marked with crosses, ${ }^{25}$ fell prey to the marauders. Most of the survivors decided to flee from the city, heading mainly eastward and southeastward - to Ruse, Razgrad and Shumen. However, the progress of Russian troops, which had already crossed the mouth of the Danube before traversing the river in the ZimniceaSvishtov area, forced them to abandon these areas in a haste. By end July 1877, another group of refugees, most of which were Jews, had left Razgrad by train. ${ }^{26}$

${ }^{22}$ Ц. Керен, Съдбата на еврейските общности в Казанльк и Стара Загора по време на рускотурската война от 1877-1878 година, http://www.thebulgarianjews.org.il/_Uploads/dbs AttachedFiles/Pogromi-Zvi.pdf, p. 1 (access: 5 January 2015). The article cited was translated from its English version, originally published in the book: The Ottoman-Russian War 1877/78, ed. O. Turan, Ankara, 2007, pp. 113-130.

23 Telegram from Mr. Huyshe to Mr. Bennett, London. Chumla, 5 July 1877, in: Russian Atrocities in Asia and Europe during the Months of June, July and August 1877, Constantinople, 1877, no. 83 , p. 58.

${ }^{24}$ L. Bernhard, Les atrocitiés russes en Bulgarie et en Arménie pendant la guerre de 1877, constatées par des documents authentiques, Berlin, 1878, pp. 26, 30. It should be noted that the author of this brochure adopts a clearly anti-Russian and anti-Bulgarian stance, stressing the merits of the Turkish authorities in the normalisation of the situation in the region and the improvement of living conditions in the Ottoman Empire.

${ }^{25}$ In his book, Paul Bourde confined himself to stating that the town of Svishtov experienced only isolated cases of killings by gangs wandering around the city; P. Bourde, Russes et turques. La guerre d'Orient, vol. 1, Paris, 1878, pp. 240-242.

26 Telegram from Mr. Huyshe to Mr. Bennett, London. Chumla, 25 July 1877, in: Russian Atrocities, no. 163, p. 94. 
A similar fate befell the Jews of Karlovo. As the Russian troops were approaching, the Jewish minority (in an estimated number of 350 residents ${ }^{27}$ ) was ordered to leave the town immediately without their belongings. This was probably due to a common belief that the Jews in Karlovo cooperated with the Muslims, spying for the Turkish troops and offering refuge to the rich representatives of this ethnic group. ${ }^{28}$ Those who opposed and remained in their homes were almost entirely exterminated by Bulgarian criminals and the Cossacks serving in the Russian army. The few who decided to return to the city after the war met with hostility from the locals. Such was the end of the Jewish community in Karlovo, the majority of which have decided to settle in Plovdiv. ${ }^{29}$

The events in Svishtov and Karlovo were, however, but a prelude to the fate of the Jews of Kazanlak and Stara Zagora. The Russian troops, accompanied by Bulgarian militia, entered Kazanlak on 5 (17) July 1877, greeted with enthusiasm by the local population. Delegations from neighbouring villages and cities (such as Stara Zagora) reached the city, asking General Gurko to send soldiers to protect the local Slavic population from Turkish assaults. At the same time, the civilian Muslim population began to flee upon hearing of the significant losses of the Russian troops at the Shipka Pass, fearing retaliation. ${ }^{30}$

The Bulgarian attacks on the Turkish and Jewish population began even before the Russians reached Kazanlak. The local Jews hoped that the presence of a regular army would bring order to the town, but instead, the arrival of Russian troops only exacerbated the already complex situation. The Turks have been disarmed and their weapons handed over to the Bulgarians, who were expected to form a volunteer militia to protect the local civilian population. The prevailing chaos and the still-fresh memory of the massacres carried out by the Turks during the suppression of the April Uprising one year earlier provoked an effect opposite to that expected. The Bulgarian volunteers began murdering the Muslim residents, showing no mercy to men, women and children alike. When describing these events in Western Europe, the authorities in Istanbul emphasized Russia's role in the incidents, counting on an intervention of the world powers that would save their influence in the region. ${ }^{31}$ Such were the circumstances in which the Jewish

27 Керен, Съдбата на еврейските общности, р. 2. D. Koen does not specify the number of Jews who lived in Karlovo, merely stating that this minority was present there; see: Коен, Българските евреu, p. 16.

${ }^{28}$ Ц. Керен, Еврейската общност в Русчук. От периферия на Османската империя до столииа на Дунавския вилает 1788-1878, Sofia, 2009, pp. 284-285.

29 Керен, Съдбата на еврейските общности, р. 2. Even after the war, rumours persisted among the residents of Karlovo that, during the war, the local Jews reportedly led the units of bashi-bazouk and Circassians to the houses of wealthier Bulgarians, which were then looted so the Jews could buy the stolen possessions from the soldiers; see: Marquis of Bath, Observations on Bulgarian Affairs, London, 1880, p. 33.

30 К. Косев, С. Дойнов, Освобождението 1877-1878, Sofia, 2003, pp. 95-96.

31 Bourde, Russes et turques, pp. 278-282. 
minority in Kazanlak fell victim to Bulgarian and Cossack assaults that were most probably motivated by mere greed.

According to the account of one of the residents who managed to escape from the city: "On July 20, four Bulgarians, accompanied by a Russian soldier, came to the house of Avraam Kaneti (head of the local community); aware of his fate, he hid quickly. The bandits searched his house, and, having found nothing of value, they headed for the adjacent building belonging to Yitzhak and Yehuda Assa. Fearing for their lives, the two brothers revealed where Kaneti had concealed his money. The assailants then tortured the old man and demanded he hand over his possessions. Unsatisfied with the result, they murdered Yehuda Assa. His brother Yitzhak managed to escape". ${ }^{32}$

The apex of violence was reached on 5 August, when, despite being ordered to leave the city, a large group of Kazanlak Jews gathered at the local synagogue. According to the aforementioned account, Bulgarians and Cossacks soon appeared in the courtyard, led by a man named Simeon, who knew the local community, as he had been performing chores for the wealthy local Jews over the years; supposedly, he also revealed the residences of his former employers, which were then ransacked. Avraam Kaneti was killed at the entrance to the synagogue, while his brother Shmuel was kidnapped for ransom. However, despite the requested sum being handed over by his family, the prisoner was not released. Two weeks later, his corpse was found on the outskirts of the town. ${ }^{33}$ At the same time, the situation of the Jews trapped in the synagogue was rapidly deteriorating; deprived of food and water, they suffered greatly in this small, enclosed space under the heat of the summer sun. Eventually, they were freed after two days by Russian officers who were preparing to leave the city upon receiving information about Suleiman Pasha's army approaching from the south. In total, 38 Jews were killed in Kazanlak, 38 went missing, 112 escaped in the direction of Adrianople. 368 people followed the Russian units back over Shipka Pass. ${ }^{34}$ The accounts of the attacks carried out by Bulgarians with assistance from Cossack soldiers (even after the withdrawal of the majority of Russian troops) also find confirmation in other sources. Allegedly, the Bulgarian assailants also displayed considerable brutality, raping women and murdering everyone regardless of gender and age, with the Jewish community being the most affected of all. ${ }^{35}$

32 Казанльк в миналото и днес. Втори годишник на казанльшката дружба "Розова долина" в Sofia 1910-1921, Sofia, 1923, p. 355. As cited in: Керен, Съдбата на еврейските общности, p. 6. Unless stated otherwise, all Bulgarian-language sources were translated by the author of the present article.

33 Ibid., p. 7.

${ }^{34}$ Ibid., p. 8.

35 Telegram from Mr. Gay to the Daily Telegraph, London, Pera, 20 August 1877; Telegram from Mr. Gay to the Daily Telegraph, London, Pera, 23 August 1877, in: Russian Atrocities, nos. 208 and 215, pp. 118-120, 123-124. 
The first Russian units entered Stara Zagora on 10 (22) July 1877 and, just as in Kazanlak, they were welcomed enthusiastically by the town's Bulgarian residents. General Gurko deployed one of the militia units in the city, hoping to strengthen the patriotic sentiment among the local populace. As a result, gangs composed of local Bulgarians began to form spontaneously, their only purpose being looting and intimidating local civilians rather than defending them. ${ }^{36}$ Anguish and despair increased even further when General Gurko left the city to return to Kazanlak. Soon, reports about the troops of Suleiman Pasha approaching the city prompted the commanders to announce partial withdrawal. The retreating troops were accompanied by a large group of civilians, who feared retaliation from the Turks. The units that stayed Stara Zagora (including the militias) were soon engaged by the enemy. Artillery fire destroyed a large portion of the city and caused great losses among both defenders and the civilians that decided to stay. ${ }^{37}$

The local Jewish minority suffered as well. All Jews and Turks were ordered to remain in their homes, thus depriving them of the possibility of acquiring food and water. The Cossack troops, actively supported by Bulgarians, went from house to house to rob them of valuable items. Also assaulted were two Jews of Italian citizenship temporarily staying in the city. They managed, however, to retrieve their stolen property the very next day, following an intervention before the Russian governor of the city. ${ }^{38}$ Brutality was exhibited predominately by the Cossack soldiers; as reported by correspondents of the Jewish press in the Balkans: "I have met and spoken with hundreds of refugees, especially with Jewish families that fled before the invaders. Those who arrived from Stara Zagora recounted how every single woman and girl in their neighbourhood had been brutally raped by Gomka's Cossacks or some Orthodox Bulgarians. A 16-year-old girl was raped by 18 Russian soldiers [as stated in the original notice, but they were probably Cossacks]. Now she is dying" ${ }^{39}$ Though we should not rely too much on one single account, especially coming from a member of one of the persecuted groups, we can state with a high degree of certainty that the Cossack troops, motivated by their desire to loot, carried out numerous acts of aggression against the wealthier representatives of the civilian population, while actively assisted by groups of Bulgarians. The wave of assaults and thefts in Stara Zagora lasted nine days, and resulted in the death of about 600 people, including women and children. 38 Jews have been killed, and hundreds more - injured. ${ }^{40}$

36 Bourde, Russes et turques, p. 375.

37 Косев, Дойнов, Освобождението, pp. 97-99.

38 Керен, Съдбата на еврейските общности, р. 12.

39 Neuburger, The Russo-Turkish War, p. 60.

${ }^{40}$ In his article, Z. Keren quotes data indicating that there were about three thousand Jewish residents in the city; seе: Керен, Съдбата на еврейските общности, p. 12. D. Koen talks about 1,500 Jews and Gypsies living in Stara Zagora, although he reckons this number may be exaggerated; seе: Коен, Българските евреи, p. 19. D. Ilkov for his part believes that, before the war of 
Dmitri Ilkov, however, presents quite an opposite course of those events; in his book, he argues that, when the Russian troops entered the city, the local Jews stayed in their homes undisturbed by anyone, instead offering refuge, if not spying for the wealthy Turks, whom the Bulgarians despised the most. To make things worse, after the recapture of the city by the troops of Suleiman Pasha, they allegedly refused to give shelter to the persecuted Bulgarians. ${ }^{41}$ Ilkov's description of the events is hardly credible; he appears instead to be giving rein to his xenophobic views, picturing the Jews in the worst possible light. However, he does mention at the same time that only Christian houses were marked with crosses (just like in Svishtov, where Christian families were usually spared by the marauding gangs), and depicts an atmosphere of anxiety and tension reigning in the city in the time between the departure of General Gurko and the arrival of the Turkish troops. It seems unlikely for the Bulgarian population to have remained idle in such circumstances after having been handed Turkish weapons; they certainly undertook action in order to ensure their own safety. Some decided to take advantage of the resulting chaos and ransacked the houses of wealthier residents. The local Jews must have fallen victim of the Bulgarians around that time, as representatives of non-Christian community in the city. ${ }^{42}$

The war also affected the Jewry living in smaller town and villages. During the battle of Nikopol, artillery fire led to the destruction or damage of eight mosques and one synagogue, as well as several hundred residential buildings belonging to: Turks (400 houses), Bulgarians (120) and Jews (5). ${ }^{43}$ In Karnobat, a town located in the central region of the country, the small Jewish community (which decreased, according to some data, to just 96 people after the war $^{44}$ ) was extensively persecuted by the Circassians employed in the Turkish army. ${ }^{45}$ The Jews from Berkovitsa and Vratsa have been expelled from their hometowns, and the local synagogue has been destroyed as well in the latter. In Kyustendil, two Jews and their servant were murdered by Bulgarians. ${ }^{46}$ The looting of Jewish possessions occurred even near the end of the war. In January 1878, after the Russians had seized the town of Samokov, David Arié had his house and shop raided by the local population. ${ }^{47}$

1877-1878, Stara Zagora consisted of 4,000 houses belonging to Bulgarians, 2,400 Turkish ones and 300 houses owned by Jews; seе: Д. Илков, Принос към историята на Стара Загора, Plovdiv, 1908, p. 202.

${ }^{41}$ Илков, Принос към историята, рр. 230-232.

${ }^{42}$ Ibid., pp. 217-230.

${ }^{43}$ F. Kanitz, La Bulgarie danubienne et le Balkan. Etudes de voyage (1860-1880), Paris, 1882, p. 225.

${ }^{44}$ Коен, Българските евреи, р. 19.

${ }^{45}$ Entry: Carnobat, http://www.jewishencyclopedia.com/articles/4055-carnabat (access: 5 January 2015).

${ }^{46}$ Керен, Съдбата на еврейските общности, p. 17. In 1877, the Jewish minority in Kyustendil approximated 350; see: И. Хаджийски, Съдбата на евреите от югозападна България през 1940-1944 година, Blagoevgrad, 1998, p. 6.

47 A Sephardi Life in Southeastern Europe. The Autobiography and Journal of Gabriel Arié, 18631939, eds. E. Benbassa, A. Rodrigue, Seattle \& London, 1998, p. 71. 
The hostilities triggered a huge wave of refugees attempting to protect their families, and at least some part of their possessions, from the upcoming threat. The Turkish population would most often take the southeastern route towards Adrianople and Constantinople, but the Jews did not avoid emigration either. Shortly after the outbreak of war, about 2,200 Jews fled from Ruse, Razgrad, Silistra, Pazardzhik, Kyustendil, Pleven, Svishtov, Nikopol, Karlovo and Vidin. Most of them would head to larger urban centres, primarily to Shumen (751 people), Sofia (700), Plovdiv (399) Varna (242) and Samokov (100). Jewish refugees from Lom, Vratsa, Berkovitsa and several other towns emigrated to Adrianople (4,000 people) and to Constantinople, where their number was allegedly significant. Most of them returned to their previous places of residence after the war had ended. ${ }^{48}$

It appears, however, that these anti-Jewish incidents did not affect significantly the Jews' general stance on their Bulgarian neighbours during the conflict. There are known cases of Jews serving in the popular mobilisation militias, volunteer formations made up of Bulgarians fighting on the Russian side. ${ }^{49}$ The names invoked most often in this context are Moses Kalev of Plovdiv, and Leon Krudov of Samokov. There were also cases of Jews serving in the Russian army, who decided to settle in Bulgaria after the war. ${ }^{50}$

Some Jews also displayed commitment to the local society by offering help and shelter to Bulgarians. The house of Chelebon Farhi in Sofia became refuge to the hegumen of the Dragalevtsi Monastery, Avksentij, sympathiser of the Bulgarian national liberation movement. In Tatar Pazardzhik (now Pazardzhik), a group of young Jews organised a vigilante group in order to protect the possessions of Bulgarian families that have fled and their own, as well as to defend the remaining population from violent attacks by the bashi-bazouk. A fire brigade was also established in this town under the leadership of Gabriel Seliktar; their task was to extinguish fires in Bulgarian and Jewish houses and shops. ${ }^{51}$

Ultimately though, the Jewish community of Sofia displayed the greatest motivation of all. Their resistance was decisive in preventing the city from being completely burned down by the Turkish army. Volunteer fire brigades made up of young Jews were also organised to counteract the effects of bandit attacks

\footnotetext{
${ }^{48}$ Коен, Българските евреи, p. 16. Adrianople became the destination of other ethnic groups as well. Back in late August 1877, the number of Turks, Tartars, Christians and Jews fleeing the military operations amounted to more than 10 thousand; see: Telegram from Mr. Gay to the Daily Telegraph, 19 August 1877, in: Russian Atrocities, no. 207, p. 114.

49 For more on the Bulgarian popular mobilisation units, see: И. Христов, С. Тодоров, Опълчението 1877/1878, Sofia, 1981; А. Анчев, Българското опълчение, Sofia, 1968; С.И. Кисов, Българското опълчение в освободителната руско-турска война 1877-1878. Спомени на запасния подполковник, Sofia, 1902.

50 Неделева, Място и роля, р. 45.

51 Мордехай, Освобождението, pp. 19-20.
} 
by the bashi-bazouk, Circassian mercenaries and common criminals prowling the city. ${ }^{52}$ When Sofia was finally seized by the Russians, two Jews were part of the delegation, which welcomed General Gurko as commander of the Russian troops. ${ }^{53}$

A similar scenario occurred in Ruse. As a result of Russian artillery shelling from the other side of the river, a large portion of the city was destroyed - the Jewish and Armenian districts being affected the most. However, the situation of the local Jewry did not differ considerably from that of other residents after all, and the Bulgarians have apparently maintained a tolerant attitude towards that minority throughout the whole conflict. ${ }^{54}$

One certain fact is that the Russo-Turkish war of 1877-1878 has contributed to considerable suffering among all civilians - Bulgarians, Turks, Jews and other minorities alike. While, in the case of the former two communities, we might say that their fate has already been sufficiently covered and is generally known to a wider audience, the circumstances involving the Jewish community remain largely on the sidelines of the historical narration.

The anti-Jewish excesses in the war-stricken areas occurred primarily during the first stage of the conflict, triggered by the prevailing chaos and the population's feeling of distress in view of its own situation. The anxiety was particularly palpable in Kazanlak and Stara Zagora, where a moment of euphoria aroused by the arrival of Russian troops was almost immediately replaced by the threat from the upcoming Turkish troops. The accounts quoted in the present article suggest that the persecutions of the Jewish population occurred mainly in smaller towns and villages (Svishtov, Karlovo, Kazanlak, Karnobat and others), and that the perpetrators of these, operating with the help and under the cover of Cossack units, were motivated primarily by profit. The ambiguous attitude of the Jews towards the Ottoman Empire in the previous years and during the war alike was not without significance either; on the one hand, it resulted in an increasing aversion to this group, and on the other, it gave rise to allegations of covert support for the Turks. Indeed, the Jewish community had not adopted a common approach to the conflict, preferring to wait for further developments and act accordingly. ${ }^{55}$

Ultimately, it would be difficult to indicate one primary culprit of the assaults. Academics do draw attention to the questionable behaviour of the Cossack troops in Russian service, but they also point out that in the Western press, the Russians and Bulgarians too were perceived as more than willing to partake in looting

52 Й. Аврамов, “Поглед към историята на българските евреи през XIX век”, Годишник ОКПОЕ 1987, no. 22, pp. 75-76.

53 Their names were Samuel Behar Levi and Chaim Isaac Eshkenazi; see: Мордехай, Освобождението, p. 20. Сf. Х. Ботушаров, “Софийските евреи през 1878-1885”, Годишник ОКПОЕ 1988, vol. 23, pp. 113-116.

54 In Ruse, the Bulgarian residents were hostile, above all, towards Muslims: Turks, Circassians and Tatars; seе: Керен, Еврейската общност в Русиук, pp. 276-285.

${ }^{55}$ Мордехай, Освобождението рр. 21-22. 
and violence against civilians: "The Russians and Bulgarians compete against each other in terms of brutality against the Jewish minority in the city of Loma Palanka [now Lom]. Wherever a Jewish person appears, they are immediately assaulted. Money is extorted from Jews every day under one pretext or another. Those of their houses that survived the war have been demolished anyway". ${ }^{56}$

It appears that limiting the perspective to a mere statistical account of the number of murders and cases of looting carried out by the members of these three groups would not exhaust the issue. There is still the question of the position of the Russian command regarding the aggressive behaviour displayed against the Jewish minority by both the Cossacks and the local Slavic population. As commanders of the Cossack troops, they certainly had the authority to discipline their subordinates to some degree. And yet they proved themselves indifferent to the fate of the Jewish population, which they looked upon with a certain disgust, significantly influenced by the anti-Semitism rooted in Russian culture and their perception of the ongoing war in terms of a clash of Christianity with Islam, meaning that the local Orthodox population above all was deemed worthy of their protection. Nevertheless, violence against Jews during the conflict was incidental, its perpetrators being rather focused on the wealthier representatives of this minority.

The rights of Jews and other minorities in the reborn Bulgarian state were later formally protected by the Constitution of the Principality of Bulgaria (i.e. the Tarnovo Constitution), adopted on 16 April $1879 .{ }^{57}$ However, the idealistic premises of this document remained in conflict with the policy of unification conducted by the Bulgarian state with regard to the Jews and other minorities over the years to come. ${ }^{58}$

Researchers also point out that the Russo-Turkish war constituted a certain breakthrough in terms of the shape and popularity of xenophobic ideas in Bulgarian lands. So far, the aversion to this minority used to have a local character and stemmed primarily from the stereotypical image of the Jew ingrained in local tradition and folklore. This situation has changed only after the war, mostly due to the above-described acts of violence and the settlements of the Congress of Berlin being ultimately unfavourable to Bulgaria. Hostility towards Jews would reach a considerable scale in the $1880 \mathrm{~s},{ }^{59}$ leading to an increase in propaganda and various accusations against the Jews, as well as an attempted assertion of

\footnotetext{
56 Neuburger, The Russo-Turkish War, p. 60.

57 For more on the measures adopted in the Tarnovo constitution, see: B. Rusin, Konstytucja tyrnowska z 1879 roku - historia, ustrój, język, in: Historyczna i ponowoczesna tożsamość Słowian, eds. T. Ciesielski, J. Zatorska, A. Skoczylas, Łódź, 2012, pp. 73-95; B. Rusin, "Prawa, wolności i obowiązki człowieka i obywatela w świetle konstytucji tyrnowskiej z 1879 roku”, Meritum Rocznik Koła Naukowego Doktorantów-Historyków Uniwersytetu Warmińsko-Mazurskiego w Olsztynie 4 (2012), pp. 91-102.

58 See: Ж. Назърска, Българската държава и нейните малцинства 1879-1885, Sofia, 1999.

59 N.M. Gelber, "Jewish Life in Bulgaria", Jewish Social Studies, 8 (1946), no. 2, p. 105.
} 
pressure on the Bulgarian parliament towards adopting anti-Jewish regulations. ${ }^{60}$ The acts of violence against this minority, as well as the surge of anti-Semitism in the years following the war of 1877-1878, belie the myth - so persistent in Bulgarian historiography - of Bulgaria as a traditionally tolerant country, free of any manifestations of xenophobia and hostility towards national minorities. On the other hand, we should recognise that this tendency was still less intense than in other countries of both Eastern and Western Europe.

\section{Anti-Jewish Excesses in Bulgarian Territories of Ottoman Empire during Russo-Turkish War of 1877-1878}

\section{Abstract}

The article concentrates on anti-Jewish excesses in the Bulgarian territories of the Ottoman Empire during the Russo-Turkish War of 1877-1878. The acts of violence against this group started at the very beginning of the war, when Russian and Cossack troops crossed the Danube and entered the city of Svishtov. Local Bulgarians joined the soldiers in the looting of the Jewish district. Several Jewish residents died. The anti-Jewish incidents occurred in several other towns (Stara Zagora and Kazanlak in particular), where local Jews were murdered and their houses were robbed and plundered. The prevailing atmosphere of chaos and fear of retaliation by retreating Turkish troops triggered the local Slavic population into committing crimes and murdering their Jewish neighbours, who were also accused sometimes of being Turkish spies. The only chance of survival for the local Jews was to flee into areas free from war, and many of them did so. It seems, however, that the atrocities did not influence considerably their attitude towards Bulgarians. In many cities, the local Jewry actually displayed great care for their neighbours, actively seeking to support and protect them. The participation of Bulgarians in the attacks belies the persistent idea of themselves being a traditionally tolerant nation, free of anti-Semitic sentiments. The Russian and Cossack troops also brought in a new variety of anti-Semitism, which previously was rather rooted in the local culture and folklore.

\section{Bibliography}

Aronson I.M., Troubled Waters. The Origins of the 1881 Anti-Jewish Pogroms in Russia, Pittsburgh, 1990.

Bar-Zohar M., Beyond Hitler's Grasp. The Heroic Rescue of Bulgaria's Jews, Massachusetts, 1998.

Benbassa E., Rodrigue A. (eds.), A Sephardi Life in Southeastern Europe. The Autobiography and Journal of Gabriel Arié, 1863-1939, Seattle \& London, 1998.

Bernhard L., Les atrocitiés russes en Bulgarie et en Arménie pendant la guerre de 1877, constatées par des documents authentiques, Berlin, 1878.

Bourde P., Russes et turques. La guerre d'Orient, vol. 1, Paris, 1878.

Carnobat, http://www.jewishencyclopedia.com/articles/4055-carnabat.

${ }^{60}$ V. Kulenska, "The Antisemitic Press in Bulgaria at the End of the 19th Century", Quest. Issues in Contemporary Jewish History. Journal of Fondazione CDEC, 3 (July 2012), pp. 72-85. 
Chary F., Bulgarian Jews and the Final Solution, 1940-1944, Pittsburgh, 1972.

Daskalov R., Debating the Past. Modern Bulgarian Historiography - From Stambolov to Zhivkov, Budapest \& New York, 2011.

Franco M., Essai sur l'histoire des Israélites de l'Empire Ottoman depuis les origines jusqu’à nos jours, Paris, 1897.

Gelber N.M., “Jewish Life in Bulgaria”, Jewish Social Studies, 8 (1946), no. 2.

Kanitz F., La Bulgarie danubienne et le Balkan. Etudes de voyage (1860-1880), Paris, 1882.

Klejn Z., "Okoliczności towarzyszące ogłoszeniu niepodległości Bułgarii w 1908 roku”, in: Państwa europejskie na drodze do niepodległości (w drugiej połowie XIX i XX wieku). Studia ofiarowane Profesorowi Marianowi Zgórniakowi, eds. I. Stawowy-Kawka, W. Rojek, Kraków, 2003.

Kulenska V., "The Antisemitic Press in Bulgaria at the End of the 19th Century”, Quest. Issues in Contemporary Jewish History. Journal of Fondazione CDEC, 3 (July 2012).

Marquis of Bath, Observations on Bulgarian Affairs, London, 1880.

Marton S., "Designing citizenship. The 'Jewish question' in the debates of the Romanian parliament (1866-1869)", Quest. Issues in Contemporary Jewish History. Journal of Fondazione CDEC 3 (July 2012).

Neuburger M., “The Russo-Turkish War and the 'Eastern Jewish Question': Encounters Between Victims and Victors in Ottoman Bulgaria, 1877-8”, East European Jewish Affairs, 26 (1996), no. 2.

The Ottoman-Russian War 1877/78, ed. O. Turan, Ankara, 2007.

Rusin B., "Konstytucja tyrnowska z 1879 roku - historia, ustrój, język", in: Historyczna i ponowoczesna tożsamość Słowian, eds. T. Ciesielski, J. Zatorska, A. Skoczylas, Łódź, 2012.

Rusin B., "Polityka Rosji na Bałkanach a udział Bułgarów w wojnach rosyjsko-tureckich w XIX wieku”, in: Ślady obcego panowania w języku, kulturze i świadomości narodów południowo-słowiańskich, ed. R. Sendek, Kraków, 2011.

Rusin B., "Prawa, wolności i obowiązki człowieka i obywatela w świetle konstytucji tyrnowskiej z 1879 roku”, Meritum. Rocznik Koła Naukowego Doktorantów-Historyków Uniwersytetu Warmińsko-Mazurskiego w Olsztynie 4 (2012).

Russian Atrocities in Asia and Europe during the Months of June, July and August 1877, Constantinople, 1877.

Stefanov P., "Bulgarians and Jews throughout history", Religion in Eastern Europe, 22 (2002), no. 6.

Todorov T., The Fragility of Goodness. Why Bulgaria's Jews Survived the Holocaust, London, 2001.

Üre P., "Immediate effects of the 1877-1878 Russo-Ottoman War on the Muslims of Bulgaria", History Studies, 13 (2013).

Vezenkov A., "Reconciliation of the spirits and fusion of the interests. 'Ottomanism' as an identity politics", in: We, the People. Politics of National Peculiarity in Southeastern Europe, ed. D. Miskhova, Sofia, 2011.

Weinzierl E., The Jewish Middle Class in Vienna in the Late Nineteenth and Early Twentieth Centuries, Working Paper, Centre for Austrian Studies, October 2003, http://www.cas.umn. edu/assets/pdf/WP011.PDF.

Аврамов Й., “Поглед към историята на българските евреи през ХІХ век”, Годишник ОКПОЕ 1987, no. 22.

Аврамов Р., “Спасение” и падение. Микроикономика на държавния антисемитизъм в България 1940-1944 г., Sofia, 2012.

Ангелов Д., “Представа за ‘другия’ в българския песенен фолклор”, Българска етнология 1997, no. $1-2$. 
Анчев А., Българското опълчение, Sofia, 1968.

Генов Р., Дизраели, еврейството и антисемитизъм в България, http://dialogueeurope.org/ uploads/JewsCol/Panel101.pdf.

Депортирането на евреите от вардарска Македония, беломорска Тракия и Пирот. Март 1943 г. Документи от българските архиви, vol. 1-2, eds. Р. Аврамов, Н. Данова, Sofia, 2013.

Дойнов С., Българската общественост и руско-турската освободителна война 18771878, Sofia, 1978.

Илков Д., Принос към историята на Стара Загора, Plovdiv, 1908.

Казанльк в миналото и днес. Втори годишник на казанльиката дружба "Розова долина" в София 1910-1921, Sofia, 1923.

Калев А., Данни относно демографското положение на българските евреи (1887-1940), Годишник ОКПОЕ 16 (1981).

Калчев К., Бесарабски българи опълчениц в руско-турската война 1877-1878, Veliko Tarnovo, 1995.

Керен Ц., Еврейската общност в Русиук. От периферия на Османската империя до столица на Дунавския вилает 1788-1878, Sofia, 2009.

Керен Ц., Съдбата на еврейските общности в Казанлък и Стара Загора по време на руско-турската война от 1877-1878 година, http://www.thebulgarianjews.org.il/_ Uploads/dbsAttachedFiles/Pogromi-Zvi.pdf.

Кисов С.И., Българското опълчение в освободителната руско-турска война 1877-1878. Спомени на запасния подполковник, Sofia, 1902.

Коен Д., Българските евреи по време на Освобождението от турско владичество, in: id., Евреите в България (1878-1949). Студии, Sofia, 2008.

Косев К., Дойнов С., Освобождението 1877-1878, Sofia, 2003.

Мордехай Й., “Освобождението на България от османско владичество и българските евреи”, Годишник ОКПОЕ 1968, vol. 3.

Назърска Ж., Българската държава и нейните малиинства 1879-1885, Sofia, 1999.

Неделева П., “Място и роля на еврейската общност в българските земи (от османско владичество до 30-те години на XX в.)", Юридическо списание на НБУ 2013, vol. 2.

Тодорова О., “Евреите в българската словесност от началото на XIX век до Освобождението”, Либерален преглед 2012, part 3.

Тодорова О., “Образът на 'нечистия евреин’ в българската книжнина от XVIII-началото на XIX век и във фолклора”, Български фолклор 1993, nо. 3.

Хаджийски И., Съдбата на евреите от югозападна България през 1940-1944 година, Blagoevgrad, 1998.

Христов И., Тодоров С., Опълчението 1877/1878, Sofia, 1981.

Шеалтиел Ш., Ционизмът в България. Особености на едно лидерско движение, Sofia, 2012.

Bartlomiej Rusin (b. 1986), political scientist, Slavic philologist, PhD candidate at the Institute of Political Science and International Relations at the Jagiellonian University (Kraków, Poland); research interests: political and military history of Central, Eastern and Southern Europe in the 19th-20th cc., Holocaust, Jewish minority in the Balkans (bartlomiej.rusin@gmail.com). 